\title{
AC 2010-782: GENDER AND RACE/ETHNICITY IN ENGINEERING: PRELIMINARY FINDINGS FROM THE PROJECT TO ASSESS CLIMATE IN ENGINEERING
}

\section{Elizabeth Litzler, University of Washington}

Elizabeth Litzler is the Director for Research at the University of Washington (UW) Center for Workforce Development (CWD). Her research interests include the educational climate for undergraduate and graduate students, gender stratification in education and the workforce, and gender and families. She is skilled in both qualitative and quantitative research. Liz is the research manager for the Sloan-funded Project to Assess Climate in Engineering (PACE), the lead of the external evaluation for the National Center for Women and Information Technology, as well as the lead on UW's NSF ADVANCE internal evaluation team. She is a member of ASA, ASEE, and WEPAN.

\section{Stephanie Jaros, University of Washington}

Stephanie L. Jaros is a Consultant for the Center for Workforce Development and is also a doctoral candidate in the University of Washington's Department of Sociology. Stephanie's research interests include gender, reproduction decision-making and inter-personal power dynamics. She is a former Christine Mirzayan Science and Technology Policy Graduate Fellow with the National Academies, served as a consultant for the Committee on National Statistics and received the Award for Excellence as a Teaching Assistant from the UW Department of Sociology. Stephanie has conducted research on behalf of the Battelle Center for Public Health Research and Evaluation, The Monteverde Institute in Costa Rica and Stanford University's Bipolar Disorders Clinic. During her time at the UW, she has earned an M.A. in Sociology, a Certificate in Women Studies and completed a Minor in Social Statistics. Stephanie also has an M.A. in the Social Sciences from The University of Chicago and a B.A. in Sociology with a concentration in Latin American Studies from Grinnell College.

\section{Suzanne Brainard, University of Washington}

Suzanne G. Brainard, Ph.D. is the Executive Director of the Center for Workforce Development (CWD) at the University of Washington. She is an Affiliate Professor in Human-Centered Design \& Engineering in the College of Engineering and an Affiliate Professor in the Department of Women Studies in the College of Arts \& Sciences at the University of Washington. Suzanne's research has focused on issues of recruitment, retention and advancement of women of all ethnicities in engineering, science and the workforce.

\section{Susan Metz, Stevens Institute of Technology}

Susan Staffin Metz is the senior advisor for the Center for Innovation in Engineering and Science Education at Stevens Institute of Technology. As a founder and president (1997 - 2002) of WEPAN, Women in Engineering Proactive Network, Susan has worked with over 200 colleges and universities to increase access and engagement of women in engineering and science through research, policy and program development. She is currently the principal investigator for ENGAGE, Engaging Students in Engineering, (www.engageengineering.org) a five year project funded by the National Science Foundation to work with 30 engineering schools to integrate research based strategies that increase retention. Susan's work at Stevens has been recognized by the White House as a recipient of the 1998 Presidential Award for Excellence in Science, Mathematics and Engineering Mentoring (PAESMEM). She was honored by the Maria Mitchell Association with the Women in Science Award in 2002 and was named an AWIS Fellow in 2007. 


\title{
Gender and Race/Ethnicity in Engineering: Preliminary Findings from the Project to Assess Climate in Engineering
}

\begin{abstract}
How do gender and race/ethnicity jointly impact students' perceptions of their experiences, abilities and their risk of attrition? This paper discusses the generalizability of the Project to Assess Climate in Engineering (PACE) findings, respondent demographics and describes some of the preliminary analysis regarding climate, confidence and risk of attrition issues for African Americans, Hispanics, Whites and men and women. Analyses confirm that students across these demographic groups have very different experiences. The findings provide additional evidence for the importance of looking at the intersection of gender and race and for separating racial and ethnic groups in analyses instead of grouping them into one under-represented minority category. The intersection of gender and race showcases the diversity of engineering student experiences and point to ways educators could re-think their programs and practices to improve the student learning environment and retention rates.
\end{abstract}

\section{Introduction}

This paper asks the questions: How do gender and race/ethnicity jointly impact students' perceptions of their experiences and their abilities? What is the impact of gender for each race/ethnicity group? What is the impact of race/ethnicity for each gender group? This analysis examines four main concept areas which measure student perceptions of their experiences, abilities and likelihood of leaving engineering: professor-student interactions, student-student interactions, self-confidence and risk of attrition.

These questions are increasingly relevant as a result of expected demographic shifts in the US population. The US Census Bureau projects that by 2050 all ethnic minority groups will comprise 54 percent of the United States population. ${ }^{1}$ This will be a major shift from 2008 when minorities made up one-third of the US population. Another demographic shift is related to the percentage of women pursuing undergraduate degrees--women now make up the majority (57 percent) of undergraduate students nationwide. ${ }^{2,3}$ But women and minorities have not seen the same trends occurring in engineering, where they remain severely under-represented. In an era that demands the intellectual talent of all citizens to meet the increasingly complex technological challenges across the globe, the US cannot afford to miss these opportunities to engage talented women and minority engineering students.

In response to this situation, researchers at the Center for Workforce Development began a study to take an in-depth look at the experiences of students in undergraduate engineering programs. In October 2006, the Alfred P. Sloan Foundation awarded a grant to the University of Washington for a multi-site research project intended to identify issues that affect persistence among engineering undergraduates while paying specific attention to the intersection of race, gender and academic experience. The purpose of the Project to Assess Climate in Engineering (PACE) was to provide methodologically sound data that would be a catalyst for climate change at the 22 participating engineering schools. 
While research clearly identifies barriers for students in engineering, it is unreasonable to assume that women and under-represented minorities universally share similar experiences. In fact, prior research indicates that people's experiences are informed by the intersection of race and gender. ${ }^{4,5}$ Very little research has been able to examine engineering student experiences at the intersection of gender and race. As a multi-site study based on data from diverse undergraduate engineering programs, and with significant numbers of African American and Hispanic respondents, PACE is uniquely suited to address this gap in the literature and identify how gender and race jointly affect student experiences. The results of this study are of increasing importance as more research relates certain types of student interactions to interest in engineering majors, and pursuit of an engineering career. ${ }^{6}$

\section{Background}

A recent report from the National Action Council for Minorities in Engineering, Inc. (NACME) details the current state of affairs for minorities in engineering. ${ }^{7}$ While the findings differ depending on which ethnic group is referenced, the report indicates that in 2005, approximately 12 percent of bachelor's degrees in engineering went to under-represented minorities (URMs). Overall, the proportion of all engineering bachelor's degrees awarded to URMs has declined from 1995 to 2005 with the notable exception of American Indians/Alaska Natives. ${ }^{7}$

In spite of the decrease in the proportion of degrees awarded, first year enrollments among URMs in engineering have improved at the aggregate level. Among first-year, full-time engineering undergraduates between 1996 and 2006, Latinos/as experienced the largest growth with an 82 percent increase in enrollment, up from 4,814 to 8,773. Native Americans followed with a 74 percent increase, from 410 to 715, followed by African Americans with a 14 percent gain from 6,245 to $7,112 .^{8}$ Although first year enrollments are experiencing an upward trend among these URMs, total undergraduate enrollment tells a different story. While Latinos/as and Native Americans have each increased their total undergraduate engineering enrollment numbers, the number of all enrolled African American engineering undergraduates actually declined between 1996 to $2006(24,922$ to 23,414$){ }^{8}$

Several studies have found that URMs graduate at higher rates when they are enrolled in programs with others of similar racial or ethnic background. ${ }^{9}$ These studies indirectly suggest that climate and demographic composition are important factors in URM retention, insofar as students who feel included and less marginalized are more likely to persist. Inclusion can be achieved in ways other than demographic composition and deserves additional attention. Brown, Morning and Watkins ${ }^{10}$ studied African American engineering students' perceptions of climate and institutional retention. They found that African American students enrolled at HBCUs had more positive perceptions of climate but when the type of university was controlled for, persistence was indirectly related to the amount of perceived racism and discrimination. Environmental factors, then, also have an important impact on retention.

The NACME ${ }^{11}$ report also notes structural barriers that deter minorities from entering engineering in the first place. These structural barriers include tuition increases coupled with decreases in government grants available to defer the cost of attending college. Additionally, NACME explores the differential impact of student loans on families given the marked increase 
in the number of people who take on such debt. Citing research by the US General Accounting Office, the authors report that a transition of 1,000 dollars from loans to grants among lowincome students improves the probability of graduation by 17 percent. $^{11}$

Research suggests that women's educational experiences differ considerably from those of men even when they attend the same institutions and the same classes. According to the report, Women and Men of the Engineering Path, ${ }^{12}$ women and men earn similar grades in engineering courses but only 42 percent of women complete their degrees compared with 62 percent of men. Thus, academic performance does not seem to account for this difference. In fact, women who leave engineering have higher grades than the men who leave. ${ }^{12}$

Grandy ${ }^{13}$ concluded that women who earned engineering degrees found their courses more difficult and less enjoyable than did men. Also, women rated their study skills more highly than did men, while the opposite was true for problem-solving skills and in self-image as future engineers. McIlwee and Robinson ${ }^{14}$ concluded that women were more successful in the classroom than in the laboratory which coincides with findings from Brainard, Metz and Gilmore $^{15}$ that indicated women were less comfortable using lab equipment than were men. Based on data from 400 undergraduate engineering students at the University of California at Davis, Sax $^{16}$ found both men and women believed their professors to be fair and were equally comfortable requesting help from instructors outside of class. Thirty percent of women but only 15 percent of men, however, indicated they were uncomfortable participating in class and also concerned with whether or not they would complete their engineering degrees.

Since the 1982 report “The Campus Climate: A Chilly One for Women?”, study after study has highlighted challenges faced uniquely by women. ${ }^{17}$ Eight years after the AAC report concluded that the campus learning environment negatively affects the self-confidence of women and diminishes their academic and professional aspirations during and after college, Crawford and MacLeod ${ }^{18}$ reported that women's academic performance is inhibited by low self-esteem across all fields of higher education. Female students tend to feel less confident in their intellectual abilities, and they tend to think they must be very prepared and know a great deal before expressing their ideas in class. Women often do not interact in classrooms out of fear that they will look stupid to others. Rayman and Brett ${ }^{19}$ also found that compared with men, women have lower self-confidence, perceived ability and self-reliance even though their grade point averages are equal to or higher than those of men. Brainard, Metz and Gilmore ${ }^{20}$ found that the perceived levels of self-confidence of females in engineering and physics courses are lower than that of male students in these areas. In addition, females report an overall lower level of academic confidence than do males. Women begin their undergraduate studies in science, math and engineering with high levels of self-confidence in their abilities in these areas, but experience sharp declines at the end of their first year. Brainard and Carlin ${ }^{21}$ reported that of those women who completed engineering degrees, at least 25 percent cite a lack of self-confidence as a major barrier to success. By senior year, this percentage increases to 44 percent.

\section{PACE Survey}

The Project to Assess Climate in Engineering (PACE) study had three main data collection components: an online student survey for undergraduates in engineering, interviews with current 
undergraduate engineering students, and interviews with undergraduate students who left engineering for another major at their university. All PACE schools received a final report that included an overview of methods, discussion of statistically significant findings and general trends, interview results, recommendations and a detailed analysis of each survey question response disaggregated by gender and race/ethnicity. Each school was also provided with the means of three schools of their choice for anonymized benchmarking. Because of the scope of the project, focusing on 22 engineering schools with in-depth surveys and face-to-face interviews collected with uniform methodologies, the findings from the PACE study provide an unprecedented opportunity to examine undergraduate experiences in engineering.

Undergraduate engineering students were sampled from a diverse set of one-tiered undergraduate institutions using a stratified random sample with oversamples of women and under-represented minorities. To reduce variation across sites, we restricted the PACE study to those undergraduate engineering programs defined as one-tiered. In other words, each of the programs either enrolls its students directly from high school into the College/School of Engineering and/or provides an engineering advisor to students during the first year who indicated an interest in engineering on their college application form. Between February and June of 2008, 38,376 engineering undergraduate students were invited to participate in the PACE online climate survey and 10,554 students responded. The response rate at individual institutions ranged from seven percent to 52 percent with an overall mean of 29 percent and a median of 28 percent. Three strategies were used to address and reduce the low response rate typically associated with web-based surveys. First, students received up to four total emails. Second, each email was sent from the local engineering dean or site liaison, and third, schools were given 100 dollars to use as in incentive which they could supplement with their own funds.

The PACE survey instrument was pre-tested on undergraduate engineering students at a Pacific Northwest university not included in the PACE project. Prior to fielding, the survey instrument was also reviewed by a panel of experts in the field of science and engineering diversity and approved by the University of Washington's Institutional Review Board (IRB) and each local school's IRB. The final PACE instrument took respondents approximately 15 minutes to complete 132 items. Questions were divided into the following categories: Quality of Teaching, Professors, Teaching Assistants, Labs, Resources, Student Interaction, Extracurricular Activities, Personal Experience, Perceptions of Engineering Career, Perceptions of Engineering Major, Confidence and Demographic Information. Personal Experience included nine questions relevant to sensitive issues such as gender and race discrimination and harassment. Transfer students were asked to complete an additional set of 24 questions, five of which were restricted to community college transfer students. The survey instrument was analyzed and internal consistency coefficients showed adequate to excellent internal consistency with a mean $\alpha$ of .77.

\section{Data}

There were 373 African American, 139 Native American, and 1,240 Hispanic respondents to the survey. The PACE survey data are unique because of the large number of under-represented minorities (URMs) who answered the survey, enabling analysis by racial and ethnic group which is not common in engineering studies. The data answer the continued call for analyses that do not combine all URMs into one group, but instead focus on the experiences of each racial and 
ethnic group, as well as disaggregating by gender and race/ethnicity. ${ }^{22,23}$ This type of analysis is often difficult because of concerns about confidentiality and cell sizes too small to conduct appropriate analyses.

This paper focuses on African Americans, Hispanic Americans, and White Americans. No one school accounts for more than 13 percent of the African American survey respondents and every school contributes to this number. For Hispanic Americans, one school contributes 22 percent of the survey respondents, two schools combined contribute another 28 percent, and all the other schools contribute to the Hispanic American respondent number. Thus, the findings discussed in this paper are not representative of only one or two schools, but instead are generalizable across schools.

On account of an extremely low response rate at one school, and outlying values on questions of interest at another school, the following analysis is based on data from 20 of the 22 PACE schools. The 22 PACE schools are composed of 77 percent public institutions, 18 percent minority-serving institutions and 55 percent are classified by Carnegie as having very high research activity (RUVH).

\section{Variables and Descriptive Statistics}

Table 1 lists the survey questions with the exact wording from the survey. These variables were chosen for the importance of these factors in the literature for student retention and progress.

Table 1. Survey Questions of Interest by Conceptual Area

Professor-Student Interaction (Never, Rarely, Sometimes, Usually, All the Time)

Do your professors inspire you to study engineering?

Are you comfortable asking questions in class?

Do your professors care whether or not you learn the course material?

Student-Student Interaction (Never, Rarely, Sometimes, Usually, All the Time)

Do you feel like you are part of an engineering community?

Do other students take your comments/suggestions in class seriously?

Do students compete with each other in your classes?

Do engineering students help each other succeed in class?

Confidence (Strongly Disagree, Somewhat Disagree, Neutral, Somewhat Agree, Strongly Agree)

I am confident in my ability to succeed in my college engineering courses

Risk of Attrition (Strongly Disagree, Somewhat Disagree, Neutral, Somewhat Agree, Strongly Agree)

I have no desire to declare a non-engineering major (e.g. biology, theater, English, philosophy)

I can think of other majors that I would like better than engineering 
Table 2 reports the means and standard deviations of the ten variables of interest by gender and race. The variable means are based on the dichotomous values as described in the Methods section.

Table 2. Means (Standard Deviations) for Ten Questions of Interest (PACE data) ${ }^{+}$

\begin{tabular}{|c|c|c|c|c|c|c|c|c|c|c|}
\hline & : & 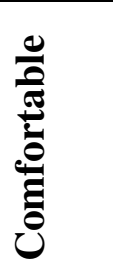 & 茪 & 己 & 党 & 雚 & 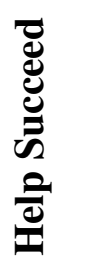 & 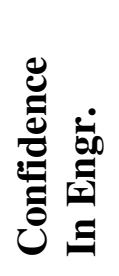 & 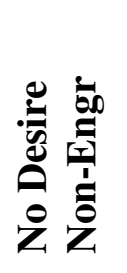 & 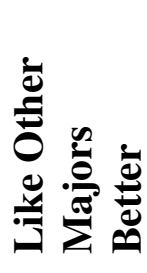 \\
\hline African & 1.41 & 1.56 & 1.69 & 1.52 & 1.58 & 1.42 & 1.58 & 1.92 & 1.70 & 1.43 \\
\hline American & $(.49)$ & $(.50)$ & $(.46)$ & $(.50)$ & $(.49)$ & (.49) & $(.49)$ & $(.28)$ & $(.46)$ & $(.50)$ \\
\hline \multirow[t]{2}{*}{ Female } & 1.39 & 1.52 & 1.67 & 1.56 & 1.58 & 1.41 & 1.53 & 1.91 & 1.66 & 1.42 \\
\hline & $(.49)$ & $(.50)$ & $(.47)$ & $(.50)$ & $(.50)$ & $(.49)$ & $(.50)$ & $(.29)$ & $(.48)$ & $(.50)$ \\
\hline \multirow[t]{2}{*}{ Male } & 1.43 & 1.59 & 1.70 & 1.50 & 1.59 & 1.42 & 1.61 & 1.92 & 1.74 & 1.44 \\
\hline & $(.50)$ & $(.49)$ & $(.46)$ & $(.50)$ & $(.49)$ & $(.50)$ & $(.49)$ & $(.27)$ & $(.44)$ & $(.50)$ \\
\hline Hispanic & 1.61 & 1.54 & 1.72 & 1.58 & 1.63 & 1.43 & 1.68 & 1.95 & 1.72 & 1.30 \\
\hline American & $(.49)$ & $(.50)$ & $(.45)$ & $(.49)$ & $(.48)$ & $(.50)$ & $(.47)$ & $(.22)$ & $(.45)$ & $(.46)$ \\
\hline \multirow[t]{2}{*}{ Female } & 1.63 & 1.46 & 1.69 & 1.60 & 1.61 & 1.46 & 1.68 & 1.93 & 1.69 & 1.35 \\
\hline & $(.48)$ & $(.50)$ & $(.46)$ & $(.49)$ & $(.49)$ & $(.50)$ & $(.47)$ & $(.26)$ & $(.46)$ & $(.48)$ \\
\hline \multirow[t]{2}{*}{ Male } & 1.60 & 1.58 & 1.73 & 1.57 & 1.64 & 1.42 & 1.68 & 1.96 & 1.74 & 1.28 \\
\hline & (.49) & $(.50)$ & $(.44)$ & $(.50)$ & $(.48)$ & $(.49)$ & $(.47)$ & $(.20)$ & $(.44)$ & $(.45)$ \\
\hline White & 1.54 & 1.59 & 1.76 & 1.61 & 1.70 & 1.37 & 1.70 & 1.95 & 1.73 & 1.32 \\
\hline American & $(.50)$ & $(.49)$ & $(.43)$ & $(.49)$ & $(.46)$ & $(.48)$ & $(.46)$ & $(.22)$ & $(.45)$ & (.47) \\
\hline \multirow{2}{*}{ Female } & 1.54 & 1.54 & 1.77 & 1.67 & 1.72 & 1.37 & 1.72 & 1.93 & 1.68 & 1.35 \\
\hline & $(.50)$ & $(.50)$ & $(.42)$ & $(.47)$ & $(.45)$ & $(.48)$ & $(.45)$ & $(.26)$ & $(.46)$ & $(.48)$ \\
\hline \multirow[t]{2}{*}{ Male } & 1.54 & 1.64 & 1.74 & 1.55 & 1.69 & 1.38 & 1.67 & 1.97 & 1.76 & 1.29 \\
\hline & $(.50)$ & $(.48)$ & $(.44)$ & $(.50)$ & $(.46)$ & $(.49)$ & $(.47)$ & $(.18)$ & $(.43)$ & $(.45)$ \\
\hline All & 1.55 & 1.57 & 1.73 & 1.59 & 1.67 & 1.40 & 1.66 & 1.94 & 1.71 & 1.35 \\
\hline Students & $(.50)$ & $(.50)$ & $(.44)$ & $(.49)$ & $(.47)$ & $(.49)$ & $(.47)$ & $(.23)$ & $(.46)$ & $(.48)$ \\
\hline \multirow[t]{2}{*}{ Female } & 1.54 & 1.52 & 1.75 & 1.64 & 1.68 & 1.39 & 1.68 & 1.92 & 1.67 & 1.38 \\
\hline & $(.50)$ & $(.50)$ & (.44) & $(.48)$ & $(.47)$ & $(.49)$ & $(.47)$ & $(.27)$ & $(.47)$ & $(.48)$ \\
\hline \multirow[t]{2}{*}{ Male } & 1.55 & 1.61 & 1.72 & 1.55 & 1.66 & 1.40 & 1.65 & 1.96 & 1.74 & 1.32 \\
\hline & $(.50)$ & $(.49)$ & $(.45)$ & $(.50)$ & $(.47)$ & $(.49)$ & $(.48)$ & $(.20)$ & $(.44)$ & $(.47)$ \\
\hline
\end{tabular}

${ }^{+}$Means computed from two point scales $(1,2)$.

\section{Methods}

In order to simplify the analysis and the reporting of the findings, the five point scales reported in Table 1 are aggregated into dichotomous variables. For scales that varied from "Never" to "All the Time", the five values are divided into 1=Never, Rarely, Sometimes and 2=Usually or All the Time. For scales that varied from Strongly Disagree to Strongly Agree, the neutral category is discarded and only students who responded with "Strongly Disagree" or "Somewhat Disagree" are coded one and those who responded "Strongly Agree" or "Somewhat Agree" are coded two. The recoding of the variables in this way creates easy to explain two by two tables. 
Because the outcome variables are all ordinal in measurement and the explanatory variables are nominal (race and gender), the analysis utilized $2 \times 2$ cross-tabulation analysis using the Chisquare test statistic, adjusted residuals and odds ratios. In a typical cross-tabulation, a statistically significant Chi-square value indicates only that the two variables are not independent. In order to know where in the table the departure from independence is, one must examine the adjusted residuals. For this analysis, adjusted residuals above the absolute value of 2.0 were considered of interest. Together, Chi-square and adjusted residuals can tell the researcher that there is an association and where that association is, but nothing about the strength of the association. For this reason, odds ratios are used to show the strength of the association. Odds ratios can be computed for any $2 \times 2$ cross-tabulation, and are the "ratio of the products of cells from diagonally opposite cells." ${ }^{24}$ When the odds ratio equals one, there is independence between the variables. Odds ratios greater or less than one indicate a departure from independence, with increasing strength as they have increasing distance from 1.0. For example, an odds ratio of 1.25 indicates a 25 percent greater likelihood of a "success" while an odds ratio of .75 indicates a 25 percent lower likelihood of "success". In this study, a "success" is the category with the highest value. The results section displays only the odds ratios and the statistical significance, not actual cells from the cross-tabulations.

\section{Results}

\section{Race/Ethnicity comparisons within gender}

The results indicate that within gender, there are important racial differences between African Americans and Whites, and Hispanic Americans and Whites. In addition, those racial differences are not always the same for men and women. Reported in Table 3 are the odds ratios for each of these cross-tabulations. The reference category is White males or White females, as appropriate.

The variables Inspire, Comfortable and Take Seriously show racial/ethnic effects that hold for both men and women. Care Learning, Community, Compete, Help Succeed, Confidence in Engr and Like Other Majors Better show racial/ethnic effects that hold for only one gender. Only one variable under consideration shows no significant relationship to race/ethnicity among males or females; there is no association between racial/ethnic category and whether someone indicates that they have no desire to declare a non-engineering major.

Compared to Whites of the same gender, African American men and women are 38 to 45 percent less likely to indicate they "usually or all the time" feel inspired by their professors to study engineering, respectively. On the other hand, Hispanic American men and women are 25 to 48 percent more likely than Whites to indicate that they "usually or all the time" feel inspired by professors to study engineering, respectively. Both male and female Hispanic American students are 23-26 percent less likely than White males and females to indicate that they "usually or all the time" feel comfortable asking questions in class. Overall, both male and female African American and Hispanic American students are less likely than White students to indicate that other students in their classes "usually or all the time" take their comments and suggestions seriously. 
Table 3. Odds Ratios for Comparisons of Race within Gender Category (Reference: Whites)

\begin{tabular}{lllll}
\hline & \multicolumn{2}{c}{ Males } & \multicolumn{2}{c}{ Females } \\
\hline & $\begin{array}{l}\text { African } \\
\text { American }\end{array}$ & $\begin{array}{l}\text { Hispanic } \\
\text { American }\end{array}$ & $\begin{array}{l}\text { African } \\
\text { American }\end{array}$ & $\begin{array}{l}\text { Hispanic } \\
\text { American }\end{array}$ \\
\hline $\begin{array}{l}\text { Professor-Student Interaction } \\
\quad \text { Inspire }\end{array}$ & $0.62^{*}$ & $1.25^{*}$ & $0.55^{*}$ & $1.48^{*}$ \\
$\quad \begin{array}{l}\text { Comfortable } \\
\quad \text { Care Learning }\end{array}$ & 0.81 & $0.77^{*}$ & 0.93 & $0.74^{*}$ \\
$\begin{array}{l}\text { Student-Student Interaction } \\
\quad \text { Community }\end{array}$ & 0.81 & 0.94 & $0.60^{*}$ & $0.69^{*}$ \\
$\quad$ Take Seriously & 0.81 & 1.06 & $0.63^{*}$ & $0.76^{*}$ \\
$\quad$ Compete & $0.64^{*}$ & $0.78^{*}$ & $0.53^{*}$ & $0.63^{*}$ \\
$\quad$ Help succeed & 1.18 & 1.18 & 1.21 & $1.44^{*}$ \\
$\quad$ Confidence & 0.78 & 1.06 & $0.44^{*}$ & 0.85 \\
$\quad$ Confidence in Engr & $0.41^{*}$ & 0.78 & 0.80 & 1.06 \\
$\quad$ Risk of Attrition & & & & \\
$\quad \begin{array}{l}\text { No Desire Non-Engr } \\
\text { Like Other Majors Better }\end{array}$ & 0.89 & 0.87 & 0.88 & 1.01 \\
\hline
\end{tabular}

*Starred items have adjusted residuals greater than $12.0 \mid$ and a statistically significant Chi-square value with $\mathrm{p}<=.05$

Note: Number of cases varies for each analysis. The minimum and maximum for males are 2855 and 4114, respectively. The minimum for females is 2565 and the maximum is 3279 .

The following racial/ethnic associations are only true of females. African American female students are 40 percent less likely than White female students to indicate that their professors "usually or all the time" care whether or not they learn the course material. The effect for Hispanic American women is similar, but not as strong. Hispanic American female students are about 30 percent less likely than White females to indicate that their professors "usually or all the time" care whether or not they learn the course material. Similarly, both African American and Hispanic American females are less likely than White females to say that they "usually or all the time" feel like they are part of an engineering community (37 and 24 percent less likely, respectively). Hispanic American female students are about 44 percent more likely than White female students to indicate that students "usually or all the time" compete with each other in their classes. African American female students are 56 percent less likely than White female students to indicate that engineering students "usually or all the time" help each other succeed in class.

There are two questions on which African American males and White males show significant departures from the expected distribution of responses. African American males are 59 percent less likely than White males to indicate that they "somewhat or strongly agree" that they are confident in their ability to succeed in their college engineering courses. In addition, African American males are almost 100 percent more likely than White males to indicate that they "somewhat or strongly agree" that they can think of other majors they would like better than engineering. 
Gender comparisons within racelethnicity

The next analysis focuses on the differences between males and females within each of the three racial/ethnic categories examined in this paper. The odds ratios for the odds of females compared to males are listed in Table 4 . The reference category is males, within each race/ethnic group.

With respect to gender differences that might exist within each racial/ethnic group, this analysis results in significant gender differences on eight of the variables for Whites, but no gender differences within the African American category and only three gender differences for Hispanics. The association of gender and these measures of climate and risk of attrition hold primarily for White students.

Table 4. Odds Ratios for Gender Comparisons within Race/Ethnic Category (Reference: Males)

\begin{tabular}{llll}
\hline & $\begin{array}{l}\text { African } \\
\text { American }\end{array}$ & $\begin{array}{l}\text { Hispanic } \\
\text { American }\end{array}$ & $\begin{array}{l}\text { White } \\
\text { American }\end{array}$ \\
\hline $\begin{array}{l}\text { Professor-Student Interaction } \\
\quad \text { Inspire }\end{array}$ & 0.86 & 1.12 & 0.97 \\
$\quad$ Comfortable & 0.74 & $0.63^{*}$ & $0.65^{*}$ \\
$\quad$ Care Learning & 0.86 & 0.84 & $1.16^{*}$ \\
$\begin{array}{l}\text { Student-Student Interaction } \\
\quad \text { Community }\end{array}$ & 1.27 & 1.13 & $1.60^{*}$ \\
$\quad$ Take Seriously & 0.95 & 0.91 & $1.13^{*}$ \\
$\quad$ Compete & 0.96 & 1.18 & 0.96 \\
$\quad$ Help succeed & 0.70 & 0.99 & $1.25^{*}$ \\
$\quad$ Confidence & & & \\
$\quad$ Confidence in Engr & 0.84 & $0.58^{*}$ & $0.43^{*}$ \\
$\quad$ Risk of Attrition & & & \\
$\quad$ No Desire Non-Engr & 0.67 & 0.79 & $0.68^{*}$ \\
$\quad$ Like Other Majors Better & 0.92 & $1.39^{*}$ & $1.35^{*}$ \\
\hline
\end{tabular}

*Starred items have adjusted residuals greater than $|2.0|$ and a statistically significant Chi-square value with $\mathrm{p}<=.05$

Note: Number of cases varies from 295 to 371 for African Americans, 973 to 1237 for Hispanic Americans and 5124 to 6305 for White Americans.

In particular, Hispanic women were 37 percent less likely than Hispanic men to indicate they are comfortable asking questions in class "usually or all the time", and 42 percent less likely to "somewhat or strongly agree" that they are confident in their ability to succeed in their college engineering courses. Hispanic women are also 39 percent more likely than Hispanic men to indicate that they "somewhat or strongly agree" that they can think of other majors they would like better than engineering.

The results for the comparison of White women and men indicate departures from independence in eight cases. Specifically, White women are less likely than White men to indicate they are "usually or all the time" comfortable asking questions in class (35 percent less), that they "somewhat or strongly agree" that they are confident in their ability to succeed in their college 
engineering courses (57 percent less), and that they "somewhat or strongly agree" that they have no desire to declare a non-engineering major (32 percent less).

On the other hand, White women are more likely than White men to indicate that their professors care about whether they learn the course material "usually or all the time" (16 percent more), that they "usually or all the time" feel like part of an engineering community (60 percent more), that they think other students take their comments/suggestions in class seriously "usually or all the time" (13 percent more), that students "usually or all the time" help each other succeed (25 percent more) and that they "somewhat or strongly agree" that they can think of other majors they would like better than engineering ( 35 percent more).

Because of the lack of results for the variable No Desire Non-Engr in Table 3, Table 5 reports on a cross-tabulation including all students of the two Risk of Attrition variables and reports frequencies and cell percentages (Table 5).

Table 5. Cross-tabulation of Risk of Attrition Variables

\begin{tabular}{|c|c|c|c|c|}
\hline \multirow{2}{*}{$\begin{array}{l}\text { No desire to declare } \\
\text { another major }\end{array}$} & \multicolumn{3}{|c|}{$\begin{array}{c}\text { Can think of other majors I } \\
\text { would like better } \\
\end{array}$} & Total \\
\hline & $\begin{array}{l}\text { Disagree } \\
\text { Agree }\end{array}$ & $\begin{array}{l}\text { Disagree } \\
802(11 \%) \\
3988(56 \%)\end{array}$ & $\begin{array}{l}\text { Agree } \\
1196(17 \%) \\
1184(16 \%)\end{array}$ & $\begin{array}{l}1998 \\
5172\end{array}$ \\
\hline & Total & 4790 & 2380 & 7170 \\
\hline
\end{tabular}

The majority of the students (56 percent) indicated that they have no desire to declare another major and they can't think of other majors they would like better. That is, a little more than half of the students indicated that there is no risk of attrition for reasons of wanting to be in a different major. The rest of the 7170 (44 percent) indicate at least some risk of attrition because of interest in another major by indicating either that they disagree that they have no desire to declare another major, or that they agree that they can think of other majors they would like better. Based on the chi-square analyses, the populations most at risk are White Women, Hispanic Women and African American Males.

\section{Discussion and Conclusion}

Having provided methodologically sound data, this study has the potential to be a catalyst for climate change in undergraduate engineering education. The findings have provided evidence that examining the joint impact of gender and race and separating racial and ethnic groups in analyses is critical. Although there were not enough subjects to examine Native Americans, there were enough subjects who are African American, Hispanic or White to conduct appropriate analyses. The joint impact of gender and race showcases the diversity of engineering student experiences and points to ways educators may need to re-think their practices, programs and policies to improve the student learning environment and retention rates for all students.

The main findings from the race/ethnicity analysis within each gender group are:

- African American and Hispanic Americans do not feel that they are taken seriously by their peers, compared to Whites. This is true of both men and women. 
- There are greater disparities between different race/ethnicity groups among women than between race/ethnicity groups among men.

- Compared to Whites, Hispanic Americans are more likely to say they are inspired by their professors while African Americans are less likely to say they feel inspired by their professors.

The main findings from the gender analysis within each race/ethnicity group are:

- No gender differences were found among African Americans.

- Among Hispanics, gender affects professor interaction, confidence and risk of attrition

- Among Whites, gender affects all four variable groups: professor interaction, student interaction, confidence and risk of attrition.

Analyses confirm that students across the demographic groups of interest have very different experiences. The findings provide additional evidence for the importance of looking at the joint impact of gender and race and for separating racial and ethnic groups in analyses instead of grouping them into one under-represented minority category. Because of the varied results from the cross-tabulation analysis, no one sentence can summarize the findings.

In general, the results confirm some of what is known about the differences in experience between women and men and between students in minority groups and majority groups, but they also provide new information related to widely cited research results. This study finds that women still feel less comfortable asking questions in class ${ }^{25}$ and less confident than men. ${ }^{26}$ These results have been well documented in the literature. ${ }^{27}$ On the other hand, this study contributes a nuanced understanding to this common finding: gender differences in confidence are only found among Hispanic Americans and Whites. There are no gender differences in confidence among African Americans. In addition, the results show race differences in confidence among men; African American men report less confidence in their engineering abilities than White men.

In addition, this study also contributes to the knowledge base the finding that there are more race/ethnicity differences among women than among men, specifically regarding professorstudent interaction and student-student interaction. The expression "double bind" is used particularly for women of color in that they face two barriers in science and engineering, as a woman and as a minority. The finding that they feel they face greater bias from professors and fellow students is a reflection of the "double bind". This double bind may also be related to the recent declines in engineering enrollments by African American women. Over the last decade, African American women, as a proportion of all African Americans, declined from a high of 34 percent of full-time undergraduate engineering enrollments in 1996 to a low of 26 percent in 2006. Accompanying this proportional decline was a drop in absolute numbers, from 8,001 in 2001 to a low of 6,290 in $2006 .{ }^{28}$ It is important to examine the causes of this trend.

Compared to Whites, African Americans and Hispanic Americans (male and female) feel that they are not taken seriously by their peers in class. This may result in increased feelings of isolation, especially given that many African Americans or Hispanic Americans are often 'solo' students in engineering classes. While this finding points to the need to educate students about bias and working in racially and ethnically diverse settings, more thought could also be given to 
interventions and professional development for faculty, who often lead by example, and to whom students listen more closely than they speak.

In a few cases, minority groups appear to have more positive experiences with their professors and peers than the majority group. Hispanic students, both male and female, are more likely to feel inspired by their professors than White students. Among Whites, women are more likely than men to say that their professors' care whether or not they learn the material, that other students take their comments seriously and that students help each other succeed in class.

Clearly, the work that has been done at institutions over the last few decades has been especially helpful for White women's sense of community in engineering. However, both African American and Hispanic American women report a lower sense of community than White women. Are non-academic or cultural communities outside of academe replacing a community in engineering? Minority students also may navigate the academic environment by joining multiple communities on campus, which meet the needs of their multiple identities. ${ }^{29,30}$ Are current methods and practices to improve the engineering community by-passing the specific needs of under-represented women students?

The findings from this study should be of interest to educational researchers, deans, practitioners, directors of women in engineering or minorities in engineering programs, and faculty who are interested in the intersection of race, gender and academic experience. In particular, the findings point to recommendations for the retention of women and under-represented minorities in engineering, and to new avenues of research. They also provide evidence that a "one size fits all" approach does not work because students with multiple group identities experience things in different ways.

Given these new findings, further study is needed to determine the programs or practices that could help put all students on equal footing. Additional research should be done to understand the specific needs of under-represented minority women in engineering, so that interventions can target those needs. There is also a need to better understand the curious finding of no gender differences among African Americans. In addition, while there are preliminary findings in this paper related to the Risk of Attrition, a multivariate analysis with proper statistical controls is necessary to examine how student experiences in engineering are related to retention and the risk of attrition. Other research has also looked bivariate associations between student experiences and retention, ${ }^{31}$ but more sophisticated methods need to be used.

The PACE project will continue to examine these questions with already collected survey and interview data. It will also be important to examine whether these findings hold at a different set of institutions, namely, two-tiered institutions where students do not enter into engineering directly. Ultimately, the goal of most educators is to increase the numbers of engineering students in general. Others believe that a particular emphasis needs to be placed increasing enrollments of women and students from under-represented minority groups. Reaching this goal will require special attention to the joint impact of gender and race/ethnicity by educational researchers and faculty. 


\section{Bibliography}

${ }^{1}$ US Census Bureau. (2008). An older and more diverse nation by midcentury. Press Release from August 14, 2008

${ }^{2}$ Commission on Professionals in Science and Technology (2006), data derived from Engineering Workforce Commission (EWC), table on "Bachelor's Degrees in Engineering by Sex, Race/Ethnicity, Citizenship and Institution, 2005" received from CPST staff May 2006.

${ }^{3}$ U.S. Department of Education, National Center for Education Statistics, Higher Education General Information Survey (HEGIS), "Fall Enrollment in Colleges and Universities" surveys, 1976 and 1980; and 1990 through 2007 Integrated Postsecondary Education Data System (IPEDS), "Fall Enrollment Survey" (IPEDS-EF:90), and Spring 2001 through Spring 2008. (This table was prepared October 2008.)

${ }^{4}$ Hooks, B. (1981). Ain't I a Woman: Black Women and Feminism. Boston: South End Press.

${ }^{5}$ Spelman, E.V. (1988) Inessential Woman: Problems of Exclusion in Feminist Thought. Boston: Beacon Press. ${ }^{6}$ Amelink, C.T. \& Creamer, E.G. (2010). Gender differences in elements of the undergraduate experience that influence satisfaction with the engineering major and the intent to pursue engineering as a career. Journal of Engineering Education, 99 (1), 81-92

${ }^{7}$ National Action Council for Minorities in Engineering. (2008). Confronting the 'New' American Dilemma, Underrepresented Minorities in Engineering: A Data-Based Look at Diversity. Executive Summary.

${ }^{8}$ Commission on Professionals in Science and Technology. (2006). Professional women and minorities: A total human resources data compendium. Sixteenth edition. Prepared by Bell, N.E., Di Fabio, N.M., and Frehill, L.M.

${ }^{9}$ Georges, A. (1999). Keeping what we've got: The impact of financial aid on minority retention in engineering. NACME Research Letter, 9, 1996.

${ }^{10}$ Brown, A.R., Morning, C. \& Watkins, C. (2005). Influence of African American engineering student perceptions of campus climate on graduation rates. Journal of Engineering Education. April: 263-271.

${ }^{11}$ Hall, R.M. \& Sandler, B.R. (1982). The Classroom Climate: A Chilly One for Women? Project on the Status and Education of Women. Washington, DC: Association of American Colleges.

${ }^{12}$ Adelman, C. (1998). Women and Men of the Engineering Path: A Model for Analyses of Undergraduate Careers. Washington DC: U.S. Department of Education and The National Institute for Science Education.

${ }^{13}$ Grandy, J. (1994). Gender and Ethnic Differences Among Science and Engineering Majors: Experiences, Achievement, and Expectations. RR-94-30. Princeton, NJ: Educational Testing Service.

${ }^{14}$ McIlwee, J.S. \& Robinson, J.G. (1992). Women in Engineering: Gender, Power and Workplace Culture. Albany, NY: State University of New York Press.

${ }^{15}$ Brainard, S.G., Metz, S.S., and Gilmore, G. (1999). WEPAN pilot climate survey: Exploring the environment for undergraduate engineering students. Proceedings of the 1999 IEEE/ISTAS Conference on Women and Technology: Historical and Professional Perspectives.

${ }^{16}$ Sax, L. (1996, November). The impact of college on post-college commitment to science careers: Gender differences in a nine-year follow-up of college freshmen. Paper presented at the Annual Meeting of the Association for the Study of Higher Education, Albuquerque, NM.

${ }^{17}$ Hall, R.M \& Sandler, B.R. (1982). The Classroom Climate: A Chilly One for Women? Project on the Status and Education of Women,. Washington, DC: Association of American Colleges.

${ }^{18}$ Crawford, M. \& MacLeod, M. (1990). Gender in the college classroom: An assessment of the "chilly climate" for women. Sex Roles 23, $101-122$.

${ }^{19}$ Rayman, P. \& Brett, B. (1995). Women science majors: What makes a difference in persistence after graduation? Journal of Higher Education, 66 (4), 388-414.

${ }^{20}$ Brainard, S.G., Metz, S.S., \& Gilmore, G. (1999). WEPAN pilot climate survey: Exploring the environment for undergraduate engineering students. Proceedings of the 1999 IEEE/ISTAS Conference on Women and Technology: Historical and Professional Perspectives.

${ }^{21}$ Brainard, S.G. \& Carlin, L. (1998). A six-year longitudinal study of undergraduate women in engineering and science. Journal of Engineering Education, 87(4), 369-375.

${ }^{22}$ George, Y., et al. (2001). In pursuit of a diverse science, technology, engineering and mathematics workforce: Recommended research priorities to enhance participation by underrepresented minorities. Washington, DC: American Association for the Advancement of Science.

${ }^{23}$ Leggon, C. (2006). Women in science: Racial and ethnic differences and the difference they make. Journal of Technology Transfer, 31: 325-333. 
${ }^{24}$ Agresti, A. \& Finlay, B. (1997). Statistical Methods for the Social Sciences. Upper Saddle River, NJ: Prentice Hall, Inc.

${ }^{25}$ Sax, L. (1996, November). The impact of college on post-college commitment to science careers: Gender differences in a nine-year follow-up of college freshmen. Paper presented at the Annual Meeting of the Association for the Study of Higher Education, Albuquerque, NM.

${ }^{26}$ Brainard, S.G., Metz, S.S., and Gilmore, G. (1999). WEPAN pilot climate survey: Exploring the environment for undergraduate engineering students. Proceedings of the 1999 IEEE/ISTAS Conference on Women and Technology: Historical and Professional Perspectives.

${ }^{27}$ Brainard, S.G. \& Carlin, L. (1998). A six-year longitudinal study of undergraduate women in engineering and science. Journal of Engineering Education, 87(4), 369-375.

${ }^{28}$ Commission on Professionals in Science and Technology. Data derived from Engineering Workforce Commission, Engineering and Technology Enrollments, Fall 1984 through Fall 2006.

${ }^{29}$ Hurtado, S. \& Carter, D.F. (1997). Effects of college transition and perceptions of the campus racial climate on latino college students' sense of belonging. Sociology of Education, 20, 324-345.

${ }^{30}$ Tate, E.D. \& Linn, M.C. (2005). How does identity shape the experiences of women of color engineering students? Journal of Science Education and Technology, 14 (5/6), 483-493.

${ }^{31}$ Amelink, C.T. \& Creamer, E. G. (2010). Gender differences in elements of the undergraduate experience that influence satisfaction with the engineering major and the intent to pursue engineering as a career. Journal of Engineering Education, 99 (1), 81-92. 